\title{
Features of career choices by young people depending on their personality maturity
}

\author{
Yuliya Rashchupkina ${ }^{{ }^{*}}$ \\ ${ }^{1}$ Don State Technical University Rostov-on-Don, Russian Federation, Gagarin Square 1, Rostov-on- \\ don, 344000, Russia
}

\begin{abstract}
As objective of this research studying of features of the choice of career by the working and jobless young people performed with different expressiveness at them this or that type of a personal maturity or immaturity. 165 respondents, jobless graduates of schools and the working university graduates participated in a research. During the research the diagnostic method and a method of poll were applied (questioning), statistical methods (factorial, regression and correlation analyses, criteria: binomial, Vilkokson, Mann-Whitney). By results of a research types of a personal maturity and immaturity at the working and jobless young people were revealed. Features of procedural characteristics of the choice of career at the working and jobless young people with different expressiveness at them this or that type of a personal maturity or personal immaturity are described. Jobless young people with a type of personal immaturity "immaturity as the expressed reflexivity" and the working young people with a personal maturity "a social and emotional maturity" carry out the choice of career mainly surely, dependently and unconsciously. The working young people with personal immaturity "immaturity as emphasis of values of individualization" make choice of profession consciously, uncertainly and dependently.
\end{abstract}

\section{Introduction}

In the conditions of the social and economic development and social and political processes happening in the country especially relevant for young people is a choice of career. For this category of people the choice of career has huge value as influences further development of their personality, forms their course of life and defines a further way of life of youth of the country. Because, how correct will be the choice of career by young people, conscious and intelligent, independent and sure, the intellectual potential of the country will depend. All this updates a problem of studying of the choice of career by the working and jobless young people taking into account their personal maturity or personal immaturity in the modern world.

In psychological science the choice of career is considered by most of domestic and foreign authors as the main vital choice of the personality (E.A. Klimov, A.A. Komlev, L.M. Mitina, N.S. Pryazhnikov, A. Maslou, etc.) $[6 ; 9 ; 14 ; 15]$, features of characteristics of

*Corresponding author: yulk-r@mail.ru 
the choice of career depending on a sex of respondents (S.T. Dzhaneryan, L.A. Zaytseva, O.M. Razumnikova, D.A. Luzzo, etc.) $[2 ; 4 ; 12 ; 16]$, intelligence and independence of the vital choice in connection with age of the subject (A.L. Shchebetov), conditionality of an originality of the vital choice of the personality her maturity (D.A. Leontyev, V.I. Nikolaeva, N.V. Pilipko, K. Rogers, etc.) are studied $[1 ; 3 ; 5 ; 7]$. However real empirical researches of interrelation of specifics of vital elections of subjects and their maturity of the personality are practically absent. Concern of psychological science concerning increase in efficiency of the choice of career leads to search of its characteristics in connection with types of a personal maturity or immaturity.

\section{Procedure and research methods}

When choosing as an object of a research of school students graduates and students graduates we were guided by the following reasons $[8 ; 10]$. First, updating of a personal maturity occurs at youthful age which age brackets coincide with the training period in high school of comprehensive school and training in higher education institution $[11 ; 13]$. Secondly, school students graduates and students graduates a priori possess a social maturity as are socialized and actively included in all spheres of public activity, but a social maturity, being one of conditions of manifestation of a personal maturity, does not mean formation of a maturity of the personality yet in general. Thirdly, school students graduates and students graduates are in a situation of personal self-determination when the personality carries out the most significant vital elections. Such social situation of development updates a reflection of the personality concerning this or that vital choice and creation of the most desirable for it a way of life, career type. Fourthly, complex studying of the choice of career was not so far a subject of a psychological research therefore studying of a personal maturity of school students graduates and students graduates is the first step in the long term of studying of vital elections of data, or other groups which are at a stage of personal and professional self-determination.

In this regard as the purpose of the real research studying of features of the choice of career (its procedural characteristics) by the working and jobless young people performed with different expressiveness at them this or that type of a personal maturity or personal immaturity.

Empirical object of a research were 165 respondents aged from 16 up to 22 years from which 79 jobless graduates of schools and 86 working university graduates. The choice of subjects of these age groups is caused by the fact that they are representatives of modern youth, they should create society and to participate actively in public life.

For studying of specifics of characteristics of the choice of career at graduates of schools and higher education institutions in connection with a type of their personal maturity / immaturity we used poll methods (questioning), testings, mathematical methods of data processing. For studying of the choice of career the questionnaire S.T. Dzhaneryan, was used by L.A. Zaytseva. The personal properties causing a personal maturity of the subjects making vital elections were studied by tests for a reflection and the self-relation, E.B. Fantalova's technique for studying of level of a ratio of value and availability in various vital spheres and modification of a technique "Diagnostics of self-updating of the personality" in adaptation N.F. Kalina, questionnaires "Diagnostics of strong-willed selfchecking", "Style of self-control of behavior" of V.I. Morosanova, modification of questionnaires "The level of subjective control", "Diagnostics of social and psychological adaptation" of K. Rogers and R. Daymond and "16 factorial personal questionnaire" of R. Kettell.

The analysis of results was carried out by means of methods of statistical data processing (STATISTICA 6). For mathematical data processing the factorial analysis, the 
multiple linear regression analysis (coefficient of determination of $\mathrm{R}^{2}$ were used at $\mathrm{p} \leq 0.05$ ), check of distribution of values of indicators to normality, the procedure of a kvartilirovaniye, nonparametric criteria of mathematical statistics: binomial, Friedman, Vilkokson, Mann-Whitney, the rank correlation analysis (Spirmen, $r$ at $\mathrm{p} \leq 0.05$ ).

The normality of distribution of indicators of personal properties was proved by Kolmogorov-Smirnov's test (at the level $\mathrm{p}<0.05$ ). Component analysis was applied by us to selection of types of a personal maturity or personal immaturity on the basis of indicators of the dominating maintenance of this or that component. By means of multiple regression analysis we set influence of separate personal properties on the maintenance of this or that component of a personal maturity or personal immaturity. Indicators of personal properties of one of components acted as dependent variable; as independent variables - indicators of personal properties of other components. Influence of personal properties of one component on personal properties of other components was analyzed at the level of $p \leq 0.05$.

The procedure of a kvartilirovaniye was applied to allocation of high, moderate and low rates of expressiveness of personal properties in each of components of a personal maturity on all selection and also to determination of expressiveness of characteristics of the choice of career in the allocated subgroups. Distribution of the respondents of degrees of expressivenesses of a certain maintenance of components of a personal maturity or personal immaturity established for all selection on groups and characteristics of the presented vital elections was proved by means of binomial criterion. The high expressiveness of these or those characteristics of the choice of career was considered empirically established if by binomial criterion their significant smallest value over other values of expressiveness of the same characteristics was confirmed. The low expressiveness of these or those characteristics was considered empirically established if by binomial criterion their significant domination over other values of expressiveness of the same characteristics was confirmed.

The coefficient of a rank correlation of Spirmen was applied to identification of a measure of correlation communication between variables, in particular to studying of communications between personal properties.

Depending on the dominating content of these or those personal properties in the general configuration of personal properties types of a personal maturity or personal immaturity were defined.

As procedural phenomenon we considered characteristics of the choice by means of the self-assessments of the subject reflecting his doubts and confidence, independence, sensibleness of the choice. As studying of procedural characteristics presents the known difficulty, about their expressiveness we judged by the self-assessments of respondents received when filling the corresponding paragraphs of questionnaires.

\section{Discussion of the results}

In the course of the research types of a personal maturity or personal immaturity at the working and jobless young people were revealed ("a social and emotional maturity", "a maturity as understanding of the social roles", "immaturity as emphasis of values of individualization" for the working young people; "immaturity as the expressed reflexivity", "immaturity as contemplation", "a maturity as self-realization" for jobless young people) (Table 1) [1].

Respondents with a type of personal immaturity "immaturity as emphasis of values of individualization" (37 people) are characterized by prevalence of values of individualization: self-confidence and freedom as independence in acts and actions. They are characterized by emotional instability, impulsivity, variability in relationships and interests; individual variability of reflexivity, manifested in high awareness of characteristic 
features to the detriment of instrumental and status features; low indicators of social adaptability, internality and emotional comfort indicate a lack of responsiveness to the social environment as a whole or to its individual manifestations, a feeling of discomfort and anxiety, a focus on external support, passivity in solving life problems or avoiding them. Correlation analysis shows a relationship between the value of Cognition, Internality $(r=0.39)$ and the Pursuit of Dominance $(r=0.33)$.

Table 1. Values of factor scales of expressiveness of the variables designating the personal properties of the subject which are grouped in components of a personal maturity.

\begin{tabular}{|c|c|c|c|}
\hline $\begin{array}{c}\text { Factors/people/type of } \\
\text { a personal maturity / } \\
\text { immaturity }\end{array}$ & $\begin{array}{l}\text { The dominating } \\
\text { component }\end{array}$ & The personal properties & $\begin{array}{c}\text { Value of factorial } \\
\text { weight properties } \\
(\geq 0.4)\end{array}$ \\
\hline \multirow{5}{*}{$\begin{array}{c}\text { Factor } 1 /(37 \text { people) } / \\
\text { Immaturity as } \\
\text { emphasis } \\
\text { values } \\
\text { individualization } \\
\end{array}$} & \multirow{5}{*}{$\begin{array}{l}\text { Valuable and } \\
\text { motivational }\end{array}$} & Love & -0.774522 \\
\hline & & Family life & -0.781257 \\
\hline & & Self-confidence & 0.415457 \\
\hline & & Knowledge & 0.456701 \\
\hline & & Freedom & 0.445766 \\
\hline \multirow{5}{*}{$\begin{array}{c}\text { Factor } 2 /(33 \text { people }) / \\
\text { Immaturity as } \\
\text { contemplation }\end{array}$} & \multirow{5}{*}{$\begin{array}{l}\text { Valuable and } \\
\text { motivational }\end{array}$} & View of human nature & 0.535361 \\
\hline & & Interesting work & -0.458107 \\
\hline & & Nature and art & 0.573097 \\
\hline & & Material life & -0.718314 \\
\hline & & Creativity & 0.596704 \\
\hline \multirow{10}{*}{$\begin{array}{c}\text { Factor } 3 /(29 \text { people }) / \\
\text { Social and emotional } \\
\text { maturity }\end{array}$} & \multirow{6}{*}{ Self-regulatory } & Escapism & -0.723610 \\
\hline & & Adaptation & 0.878316 \\
\hline & & Emotional comfort & 0.813044 \\
\hline & & Internality & 0.845060 \\
\hline & & Aspiration to domination & 0.503945 \\
\hline & & $\begin{array}{c}\text { General level of self- } \\
\text { control }\end{array}$ & 0.600311 \\
\hline & \multirow{2}{*}{$\begin{array}{l}\text { Emotional and strong- } \\
\text { willed }\end{array}$} & $\begin{array}{c}\text { Strong-willed self- } \\
\text { checking }\end{array}$ & 0.622636 \\
\hline & & Emotional stability & 0.620590 \\
\hline & $\begin{array}{l}\text { Valuable and } \\
\text { motivational }\end{array}$ & Orientation in time & 0.512194 \\
\hline & Reflexive & Global self-relation & 0.709324 \\
\hline \multirow{3}{*}{$\begin{array}{c}\text { Factor } 4 /(25 \text { people }) / \\
\text { Immaturity as } \\
\text { expressed } \\
\text { reflexivity }\end{array}$} & \multirow{3}{*}{ Reflexive } & $\begin{array}{c}\begin{array}{c}\text { Social environment, life } \\
\text { events }\end{array} \\
\end{array}$ & 0.743855 \\
\hline & & Tool lines & 0.779075 \\
\hline & & Intentsionalny lines & 0.717301 \\
\hline \multirow{6}{*}{$\begin{array}{c}\text { Factor } 5 /(21 \text { people }) / \\
\text { Maturity as } \\
\text { self-realization }\end{array}$} & \multirow{6}{*}{$\begin{array}{l}\text { Valuable and } \\
\text { motivational }\end{array}$} & Need for knowledge & 0.555016 \\
\hline & & Aspiration to creativity & 0.426671 \\
\hline & & Autonomy & 0.732360 \\
\hline & & Spontaneity & 0.627726 \\
\hline & & Sociability & 0.739027 \\
\hline & & $\begin{array}{c}\text { Flexibility in } \\
\text { communication }\end{array}$ & 0.698473 \\
\hline \multirow{4}{*}{$\begin{array}{c}\text { Factor } 6 /(20 \text { people }) / \\
\text { Maturity as } \\
\text { understanding of the } \\
\text { social roles }\end{array}$} & \multirow{2}{*}{$\begin{array}{l}\text { Valuable and } \\
\text { motivational }\end{array}$} & Active life & 0.481170 \\
\hline & & Friends & -0.494806 \\
\hline & \multirow{2}{*}{ Reflexive } & Status lines & 0.859015 \\
\hline & & Characterologic lines & -0.840665 \\
\hline
\end{tabular}

Respondents with a type of personal immaturity "immaturity as contemplation" (33 
people) are characterized by prevalence of motives values of individualization ("Creativity") and the low importance of values of adaptation ("Financially secure life"). They are characterized by emotional instability in interests, mood and relationships, refusal to work and rapid fatigue; low reflexivity, manifested in a low awareness of both their competence and socio-life events. Along with this, they are low adapted, dependent on others and prone to submission in interpersonal relationships, experience emotional discomfort amid avoiding problem solving.

Respondents with the type of personal maturity "social and emotional maturity" (29 persons) are characterized by high social adaptation, sense of stability, responsibility for their actions and behavior, autonomy and initiative, independence from others and desire to control their social environment; high rates of development of volitional self-regulation show the ability of respondents to consciously manage their actions, states and motives in different situations, to respond flexibly and adequately to changes in environmental conditions, and the high emotional stability inherent in respondents of this group is an indicator of their emotional maturity, calm and self-confidence, continuity in their plans and attachments. Respondents are able to enjoy the current moment and understand the existential value of life "here and now," to treat themselves positively, to value themselves for personal qualities, for acts and actions performed. Regression analysis results (adaptation measure - dependent variable; $\mathrm{R}^{2}=0.87$ ) show that the high adaptation of respondents is provided by a pronounced desire for dominance, emotional comfort and internal locus of control, the influence of which is dominant.

Respondents with a type of personal immaturity "immaturity as the expressed reflexivity" (25 people) are characterized by the expressed reflexivity, know what is wanted, realize the requirements and aspire to the ideals. However, they are characterized by emotional instability, constant mood changes influenced by feelings, rapid fatigue; immersion in past experiences, rigor, uncertainty about its attractiveness to the interviewer, manifested in the lack of desire for social contacts; lack of responsiveness to the social environment, orientation towards support from others, passivity in solving life problems or avoiding them, attribution of their successes and achievements to external circumstances luck, assistance of others. The results of the correlation analysis showed a relationship between the indicator of instrumental traits and "Internality in the field of achievements" $(\mathrm{r}=0.33)$.

Respondents with a type of a personal maturity "a maturity as self-realization" (21 people) are characterized by prevalence of motives values of individualization ("Autonomy") and socialization (dispositional "Sociability") in their hierarchy of values. They are characterized by high rates of development of will self-regulation; positive attitude towards yourself, ability to value yourself for personal qualities, for actions and actions performed and low awareness of their instrumental features and social and life events; the high indicators of social adaptation, internality, emotional comfort and desire for dominance indicate the adaptation to the conditions of the social environment experienced by the feeling of well-being of their lives, the prevalence of positive emotions, responsibility for their actions, the tendency to suppress another person in interpersonal relations, to feel superiority over others. Regression analysis results (disposition contact index - dependent variable; $\mathrm{R}^{2}=0.91$ ) show that high contact is ensured by the expressed high awareness of characteristic, status, instrumental features of their personality and social-life events, the influence of awareness of characteristic features is dominant.

Respondents with a type of a personal maturity "a maturity as understanding of social roles" ( 20 people) are characterized by the high level of understanding of the social status and social roles against the background of low awareness of the characterological lines. They note the high value of individualization ("Active life") and low value of socialization ("Presence of good and loyal friends"). Characterized by emotional rigor and instability, 
respondents control their actions, which ensures their performance; low rates of dominance indicate a tendency to submission, softness and subjugation in interpersonal relationships. In respondents with a high expression of the value of "Active Life," there is an expression of awareness of the social environment $(\mathrm{r}=0.37)$ and of the desire for dominance $(\mathrm{r}=0.37)$.

\section{Conclusions}

Procedural characteristics (confidence, independence, sensibleness) of the choice of career at these groups of respondents were studied and described. By means of descriptive statistics and binomial criterion it was established that jobless young people with different expressiveness of a personal maturity or personal immaturity surely carry out the professional choice, is more often unconsciously and dependently, under the influence of circumstances or by means of councils of seniors. The working young people with different expressiveness of a personal maturity or personal immaturity make the choice of career surely and consciously, correlating it to the opportunities and interests, but is dependent, relying on the help of other people more often.

It was also established that jobless young people with a type of personal immaturity "immaturity as the expressed reflexivity" and the working young people with a personal maturity "a social and emotional maturity" carry out the choice of career mainly surely, dependently and unconsciously. It can demonstrate to understanding by such subjects of the fact that it is necessary for them time at present and as their content of the choice will affect their success of activity in the future. In turn, the working young people with personal immaturity "immaturity as emphasis of values of individualization" make choice of profession consciously, uncertainly and dependently that indicates ability of such subjects to analyze own behavior and possible alternatives and ability to take the responsibility for the perfect choice.

\section{References}

1. A. Brown, J. Bimrose, S.-A. Barnes, D. Hughes. Journal of Vocational Behavior, 80, 754-761 (2012). DOI: 10.1016/j.jvb.2012.01.003.

2. A.Hirschi. Journal of Vocational Behavior, 79, 340-348 (2011). DOI: 10.1016/j.jvb.2011.05.005.

3. A.Hirschi, S.G.Niles, P.Akos. Journal of Adolescence, 34, 173-182 (2011). DOI: 10.1016/j.adolescence.2009.12.009.

4. E.L.Soldatova, I.A.Shlyapnikova. Procedia - Social and Behavioral Sciences, 86, 283288 (2013). DOI: 10.1016/j.sbspro.2013.08.565.

5. Fr.D.Mann, C.G.DeYoung, R.F.Krueger. Personality and Individual Differences (Available online 7 December 2019, 109737, In Press). DOI: 10.1016/j.paid.2019.109737.

6. G.Vilhjálmsdóttir, G.B.Arnkelsson. Journal of Vocational Behavior, 83, 581-590 (2013). DOI: 10.1016/j.jvb.2013.08.002.

7. H.Mishkin, N.Wangrowicz, D.Dori, Y.J.Dori. Procedia - Social and Behavioral Sciences, 228, 222-228 (2016). DOI: 10.1016/j.sbspro.2016.07.033.

8. J. Bimrose, R. Mulvey. British Journal of Guidance and Counselling, 43, 337-350 (2015). DOI: 10.1080/03069885.2015.1017803.

9. J.E. Bright, R.G. Pryor, L. Harpham. Journal of Vocational Behavior, 66, 561-576 (2005). DOI: 10.1016/j.jvb.2004.05.001. 
10. L.Gren, R.Torkar,R.Feldt. Journal of Systems and Software, 124, 104-119 (2017). DOI: $10.1016 /$ j.jss.2016.11.024.

11. M.Guranda. Procedia - Social and Behavioral Sciences, 136, 522-526 (2014). DOI: 10.1016/j.sbspro.2014.05.368.

12. M.L.Savickas, E.J. Porfeli. Journal of Career Assessment, 19, 355-374 (2011). DOI: 10.1177/1069072711409342. E-ISSN: 2536-4758.

13. M.Noorani, Z. Refahi. Procedia - Social and Behavioral Sciences, 174, 2234-2239 (2015). DOI: 10.1016/j.sbspro.2015.01.880.

14. P.A.Creed, T.Fallon, M.Hood. Journal of Vocational Behavior, 74, 219-229 (2009). DOI: $10.1016 /$ j.jvb.2008.12.004.

15. R.Paloş, L.Drobot. Procedia - Social and Behavioral Sciences, 2, 3407-3411 (2010). DOI: $10.1016 /$ j.sbspro.2010.03.524.

16. V.Kulcsár, A.Dobrean, I.Gati. Journal of Vocational Behavior, 116, 303-346 (2020). DOI: $10.1016 /$ j.jvb.2019.103346. 